\title{
Post-colonial Theory of Homi K. Bhabha: Translator's and Translatologist's Reflection
}

\author{
A. Milostivaya \\ Department of Translation Studies \\ North-Caucasus Federal University (NCFU) \\ Stavropol, Russia \\ xyscha@mail.ru
}

\author{
E. Nazarenko \\ Department of Translation Studies \\ North-Caucasus Federal University (NCFU) \\ Stavropol, Russia \\ katrin-rf@mail.ru
}

\author{
I. Makhova \\ Department of Foreign Languages \\ Stavropol State Agrarian University (SSAU) \\ Stavropol, Russia \\ zheltova.ira71@mail.ru
}

\begin{abstract}
The article is devoted to the translatological features of the monograph of famous modern philosopher Homi K. Bhabha "The Location of Culture" in the translation into the Russian language. In the current context of globalisation, the issue of interaction between representatives of different backgrounds becomes more important. Cultural interaction is most visibly reflected in migrant literature created in a so-called "third space". The theory of Homi $\mathrm{K}$. Bhabha is based on the existence of such space where cultural borders open up to each other, and creation of a new hybrid culture that combines their features and atones their differences. The term hybridity has become one of the most recurrent concepts in postcolonial cultural criticism and facilitates the revealing the understanding of the world of bilingual translators related to several cultures. Homi K. Bhabha does not claim that translated texts are hybrid. He considers that the process of translation itself leads to hybridity. More than that, the article gives special attention to English-Russian translational reflection in the process of communicative content transfer of the discussed monograph of Homi $\mathrm{K}$. Bhabha. The authors' observations reveal that the communicative equivalence accomplishment is possible on conditions of the line of translational transformations (concretization, generalisation, calquing, omission, etc.) and transliteration. The results of the research provide added value in developing such key problems in modern translatology as a description of extended meanings in the communicative act, the study of linguistic means for creating a worldview of authors of scientific texts.
\end{abstract}

Keywords—post-colonial discourse; Homi K. Bhabha; equivalence; scientific text; terminology system; system of translational means

\section{INTRODUCTION}

Translatology of the twenty-first century has increasingly shown a research interest in those matters that accentuate the relationship of the language, including discourse, structures and sociocultural dimensions of mastering the environment [1; 2]. In this approach, the focus of reflection of translator falls on axiological individual constants of particular linguaculture and their ability to act as a theoretical framework for interpreting the communication, including acting in the human studies.

The relevance of this problem is determined, firstly, by the fact that such research interest focus gets a wide range of socio-cultural issues related to the description of translation and translational specificity of discourse. As a material for the research, the authors used H.K. Bhabha's monograph "The Location of Culture" [3].

Homi K. Bhabha (born 1949) is Professor of the English and American language and literature, as well as Director of the Humanist Center at Harvard University. It is challenging to define the profession of H.K. Bhabha. He is quoted by historians, philosophers, linguists, and culturologists. It is undeniable that he is the leader of post-colonial studies direction, the author of a large number of neologisms (hybrid, mimicry, ambivalence, dissemination, etc.). In his works, H.K. Bhabha affects a wide range of topics: nationalism, postcolonial literature, the problem of the city in the global era, writing practice, translation studies, postmodernism, hermeneutics, phenomenology in exploring the history, culture and philosophy of third world countries. However, the keyword to characterise his research activity is still "postcolonialism" (post-colonial studies).

Research works of H.K. Bhabha, one of the leading contemporary philosophers and theorists of translation, at the same time contribute into obtaining more insight into the role and place of the post-colonial style of thinking in the process 
of explication picture of the world. His theory considers the theorist of translation, which is also relevant in the context of current trends in the axiological linguistics development. He is one of the most important figures in contemporary postcolonial studies and he developed a number of neologisms and key concepts such as hybridity, mimicry, differences and duality [3]. A study of post-colonial translation theory is also relevant in terms of the translatology, which is caused by the need to correct transfer of terminological information in the humanitarian scientific texts in a foreign language, which may be contrary to the expectations of carriers of the axiological target language.

\section{HOMI K. BHABHA CONTRIBUTION TO THE TRANSLATIONAL STUDIES}

In the current conditions of globalisation and the enormous growth of vehicles and means of communication, the dialogue between representatives of different backgrounds is becoming increasingly important. Works of art are created under the direct or indirect influence of verity of cultures and the language in which they are written. Especially the interaction of cultures is evident in the works of authors, established in the so-called "third space". The theory of H.K. Bhabha, introduced in 1994, is based on the existence of such space where cultural borders open up to each other, and creation of a new hybrid culture that combines their features and atones their differences[3].

Colonial and post-colonial processes move and mix the languages of the nations that, in one way or another, affects translatology. The idea of "cultural translation" most significantly is represented by H.K. Bhabha in a chapter titled "How Newness Enters the World: Postcolonial Postmodern Space Time and the Trials of Cultural Translation" in his main work "The Location of Culture" [3]. This part of the chapter is devoted to the novel "the Satanic Verses" by Indian novelist Salman Rushdie, grew up in Britain. H.K. Bhabha is concerned that this type of mixed discourse of migrants from the Indian subcontinent to 'West' could mean for the culture of Europe. He cited the example of two possible options: either the behaviour of the migrant remains unchanged throughout the process, or they are integrated into a new culture. This kind of question is strangely reminiscent of some of the main oppositions in the theory of translation: whether the translation must keep target text form, or it should operate fully as a part of the new cultural environment? What should localisation lead to: 'diversification' or 'standardisation'? In search of answers to these questions, Bhabha accesses by Walter Benjamin's essay on translation [4] and Jacques Derrida's comments [5; 6].

H.K. Bhabha considers the novel "the Satanic Verses" as a kind of translation, for example, Salman Rushdie translated the sacred in blasphemy: the name 'Mahomed' becomes 'Mahound'. This example is really similar to the translation, but this blasphemy may fairly be described as the 'transgressive act of cultural translation' [1].

H.K. Bhabha borrows the theory of untranslatability found in the assertion by Walter Benjamin, according to which 'translation itself is untranslatable' [1]. W. Benjamin actually claimed that 'the reasons for such untranslatability lie in excess of fleetingness (Flüchtigkeit)', due to which meaning is attached to the translation, and one should refer to the translation as momentary subjective positions of translator [4]. H.K. Bhabha, however, does not pay attention to this 'fleetingness' (and thus refrain from many possible puns with the word 'Flüchtling' as 'refugee' or 'fugitive'). Instead, untranslatability acts as a resistance point, the denial of full integration and the desire of the migrant for survival. Thus, it represents a way out of the binary dilemmas. Translation can be considered as a metaphor or a way of thinking and untranslatability can show the desire to go counter to the binary thinking [4].

H.K. Bhabha discusses such theory as survival. To link it with the term of 'resistance', H.K. Bhabha considering the phenomenon of untranslatability refers to the essay of Walter Benjamin, where there is a question of translation as a continuation of the life of the source text. Walter Benjamin suggests that the translations give the possibility of 'second life' for a source text. [3] Further, in order to draw a parallel between the 'life after death' and 'survival' H.K. Bhabha refers to Derrida's comments to "The Ear of the Other", where the author comes to the conclusion that:

1) Walter Benjamin alternately uses terms 'Überleben' and 'Fortleben' in meaning 'to live on',

2) French term 'survivre' ( 'survive', but literally 'to live after') is suitable for both of these theories [5].

Thus, according to H.K. Bhabha, W. Benjamin's theory can become a 'survive' (Überleben, survie), and both are associated with the problematic border between life and death. Therefore, it is possible to draw parallels between the theories of H.K. Bhabha, W. Benjamin and Derrida: 'transience' of W. Benjamin has become a 'resistance' in the works of H.K. Bhabha; what was the discussion of texts by W. Benjamin and Derrida, becomes an explanation of the people; the study of the problems associated with multiple languages has grown into a study of the problems within the same language; the boundary between life and death in Derrida's works becomes a cultural boundary migration of H.K. Bhabha; translatology is no longer seen as the language transformations but the struggle for a new cultural identity. The theory of 'survival' can be applied to the translational studies and create a completely new context. H.K. Bhabha shows the following relationship: 'If hybridity - is heresy, then blasphemy is a dream. It is neither the dream of past or present, nor the continuous present; it is neither a nostalgic dream of tradition, nor a utopian dream of modern progress; This dream of a translation as a 'survival' as Derrida translates the 'time' according to W. Benjamin's theory of 'life after death', as the law of life on the border.

According to H.K. Bhabha, 'translation demonstrates the performative nature of cultural communication'. [3] However, the wording of cultural translation refers not only to literary translation that includes two texts in two different languages but also for data transfer term it touches the process and conditions of human migration. A mixture of cultures is possible in active migration conditions, which in consequence leads to a change of a language as a reflection of reality. 
Accordingly, in such a situation, the translation receives a new status by acting as a different reality, a 'third space' [7].

H.K. Bhabha considers translation as a metaphor for the communication process, arising from the fragments on the border between languages, as well as regenerating the basis for reciprocity and expanding the boundaries of understanding, through dialogue and negotiation between cultures. Understanding of the term 'translation' is not like the adaptation of foreign culture according to the rules of host culture, not as a verbatim reproduction of a source text, where the goal of the target text is to be identical to the source text, but rather as a dynamic interaction, in which the conceptual boundaries are expanded, and the differences are seen with respect. This approach may allow more radical understanding of cultural exchange in modern society [8].

A special feature in H.K. Bhabha's research in the field of translation studies is the emphasis on 'hybridity'. The term of 'hybridity' has become one of the most recurrent concepts in postcolonial cultural criticism and facilitate to reveal the understanding of the world of bilingual translators related to several cultures. [9]. Also, this approach makes it possible to explain the main consequences of the transition from one cultural environment to another, but H.K. Bhabha does not claim that translated texts are hybrid. He considers that the process of translation itself leads to hybridity [1].

Thus, H.K. Bhabha puts more value in the term of 'translation' than it is customary seen in the classical translational studies. This theoretical approach quite differs from the descriptive studies that consider how to manage the process of translation in colonial and postcolonial contexts. H.K. Bhabha speaks of a certain set of translational features and a totally different meaning of the given term. H.K. Bhabha believes that the translational process goes through some previously established boundaries and, therefore, puts them into question. No other study has raised questions about the translational boundaries, no study has questioned how the boundaries produce the illusory opposition in society. This vision facilitates the revelation of some aspects that were previously ignored.

\section{The TRAnSLAtional Features OF THE TERM SyStem OF HOMI K. BHABHA's THEORY FROM ENGLISH INTO RUSSIAN}

It should be noted that the post-colonial discourse of H.K. Bhabha has specific lexical and syntactic idiostyle. Translational efficiency is largely determined by the degree of the relationship between a source text and a target text. In this regard, one of the central terms of the translatology is the theory of translational equivalence [10]. Translational Equivalence is a relative similarity of a source text and a target text in the absence of their identity. One should digger theoretically possible equivalence, defined by the correlation between structures and rules of the two languages, and the optimum equivalence (similarity, achieved in a particular translational act). And, in either case, the degree of similarity of a source text and a target text may be different and translational equivalence is established on different levels. The achievement of a high level of equivalence does not always guarantee the success of cross-language communication. In this regard, researchers introduced the term 'adequacy' that denotes translational conformity for requirements and conditions of the particular act of cross-language communication [11]. Translational adequacy lies in the fact that translation should optimally match specific communicative goals and tasks that vary depending on the genre, style, and appearance of a text [10].

First of all, there is a need to name three common conditions of running an adequate translation of terms. Firstly, it should be provided with an adequate translation of individual terms for a specific text. Secondly, every translated term should be checked according to the term system, appearing in the source language and the target language, which is used to denote a system of terms of any particular field of science, knowledge, technique, etc. Thirdly, the difference of terms should be taken into account that is defined by features of passing thoughts on each of these languages.

These three listed conditions must be taken into account in a process of choosing a particular translational method. In the given translation of the text, the authors used the transformations, suggested by V. N. Komissarov (transcription, transliteration, calquing, combination and division of sentences) [11], as well as by L. S. Barhudarov (omissions, additions, replacement of inflected forms, parts of speech replacement, permutations) [10].

\section{1) Lexical transformations}

This kind of transformation denotes the formal and meaningful relationships between words and phrases in a source and target texts. Among the formal transformations, the major translation techniques are:

- Transcription and transliteration are the types of translation of lexical unit by recreating its original sound or graphic form using the letters of the target language. For Example: Bhabha - Bhabha, Berger - Berger, Mahmoud Mahmud.

- Calquing is a way to transfer a lexical unit of the source language by replacing its morphemes or words (in the case of sustained phrases) with their lexical equivalence in the target language. So, for example: immigration status - status immigranta, colonial expansion - kolonial'naja jekspansija, cultural differences - kul'turnye razlichija.

The next group of lexical transformations is formed by the lexico-semantic replacements that are linked to the modification of the meaning of the lexical units. The main techniques in this group include the specification and generalisation.

- Concretization is a replacing of words or phrases of the source language, that offer the broader subject-logical meaning, with the words and phrases of the target language that offers a narrower meaning:

This process estranges any immediate access to an originary identity or a 'received' tradition [3]. - Jetot process otdaljaet ljuboj neposredstvennyj dostup $\mathrm{k}$ identichnosti ili pervonachal'noj "unasledovannoj” tradicii [12]. 
In the given example, one can observe a narrowing of the meaning in the translation due to the fact that the Russian language lexis is characterised by greater specificity than the corresponding lexical units of the English language.

Generalisation is one of the types of lexical replacement, the translation method when lexical units of a source language that offer the narrower subject-logical meaning, are replaced with the words and phrases of the target language that offers a wider meaning.

During this translational method, a translator, following the order of synthesis, replaces a term that offers more limited and more difficult content enclosed in a word or a phrase of the source text with a term that offers a broader content, but is less sophisticated and less concrete. The generalisation, as the method of concretization opposed to it, is based on generic or hypo-hyperonic relationships in the Lexis. The language form, a word or a phrase in the target text that denotes more general notion in a target language turns hyperonym towards a language form expressing the notion of the source text.

The reasons for using this type of lexical replacements in written text vary: generalisation can be used to translate the non-equivalent vocabulary when contextual conditions do not allow using a regular match or it is consciously used by the translator and depends on the cognitional level of the source text, individual preferences shaping the style of a translator. In the following example, a generalisation is used to replace a proper name (the name of the TV channel):

The first searing expose of the Bhopal disaster is made for Four [3]. - Pervaja shokirujushhaja hronika tragedii v Bhopale byla snjata dlja britanskogo telekanala [12].

\section{2) Grammatical transformations}

They were applied when the object of translation, burdened with the non-standard relationship, was a grammatical structure of the text, from a morpheme to a micro text. Among the grammatical transformations, some of the methods used in the study were:

- Replacement of parts of speech is caused by 'the difference in using words or rules of compatibility in English and Russian languages and in some cases the absence of a part of speech with the corresponding meaning in the Russian language'. [11] For example:

There must be a tribe of interpreters of such metaphors - the translators of the dissemination of texts and discourses across cultures - who can perform what Said describes as the act of secular interpretation [3]. - Dolzhno byt' plemja perevodchikov takih metafor - perevodchiki tekstovyh i diskursivnyh disseminacij $\mathrm{v}$ raznyh kul'turah, kotorye mogut vypolnit' to, chto Said opisyvaet kak akt svetskih interpretacii [12].

- The omission is caused by semantically redundant words, i.e. words expressing the meaning that can be extracted from a text, even without using it. As an example in the given text, the authors can cite the following sentence:

"In some ways it is such and such historical certainty and settled nature of that term against which I am attempting to write of the Western nation as an obscure and ubiquitous form of living the locality of culture [3]. - V nekotorom smysle imenno vopreki istoricheskoj opredelennosti i ustojchivoj prirode jetogo termina ja i pytajus' pisat' o zapadnoj nacii kak o nejasnoj i vezdesushhej forme zhizni lokal'noj kul'tury [12].

In the following example, the addition was used due to "formal" semantic components of non-equivalent phrases in the source language:

Gatherings of exiles and emigres and refugees; gathering on the edge of 'foreign' cultures; gathering at the frontiers [3]. Sobiranija izgnannikov, emigrés i bezhencev, vstrechajushhihsja na grani "chuzhih" kul'tur; sobiranija na prigranichnyh polosah [12].

- The permutation is a repositioning (reordering) language elements in a target text in comparison with a source text. For example:

How do we plot the narrative of the nation that must mediate between the teleology of progress tipping over into the 'timeless' discourse of irrationality? [3] - Kak my myslim svjazujushhee zveno $\mathbf{v}$ teleologii progressa, narrativ nacii, oprokidyvajushheesja vo «vnevremennyj» diskurs irracional'nosti? [12]

In this example, the permutation method was applied in line with the theme-rematical formation in the Russian language that differs from the English structure.

- Segmentation of a sentence is a way of translation, where the syntax structure of a sentence in the source language is converted into two or more predictive structure in the target language [11]. For example:

Such 'double-time' cannot be so simply represented as visible or flexible in 'unmediated contemplation'; nor can we accept Bakhtin's repeated attempt to read the national space as achieved only in the .fullness of time [3]. - Takoe «dvojstvennoe vremja» ne mozhet byt' prosto predstavleno kak vidimoe ili izmenchivoe v "neposredstvennom sozercanii". My ne mozhem prinjat' i neodnokratnye popytki Bahtina ponjat' nacional'noe prostranstvo kak osushhestvlennoe tol'ko v polnote vremeni [12].

In the given example, one can observe the division of a sentence during translation to the Russian language since the sentence is too long and can cause difficulties in reading.

In the translation of the term system of H.K. Bhabha, the authors have identified the following groups in terms of their translational methods:

1) Established equivalences. These equivalences have been already found use in the works of other authors working in the field of post-colonial studies. The translation of these terms is managed through having knowledge of the existing translations of literature related to the field of the research, including intercultural communication and sociology. This translation is universally recognised and it is possible to be applied when being apprised of the dictionary. In the following examples, one can observe similar situation: 
What I am attempting to formulate in this chapter are the complex strategies of cultural identification and discursive address that function in the name of 'people' or 'the nation' [3]. - Chto ja pytajus' sformulirovat' $\mathrm{v}$ jetom ocherke - jeto slozhnye strategii kul'turnoj identifikacii i diskursivnogo obrashhenija, kotorye dejstvujut v imeni "narod" ili "nacija" $i$ delajut ih neotemlemymi subjektami i objektami rjada social'nyh i literaturnyh narrativov [12].

In this case, the translation was used, as in the previous example, due to the constant equivalences that are enshrined in the dictionary:

In some ways it is the historical certainty and settled nature of that term against which I am attempting to write of the Western nation as an obscure and ubiquitous form of living the locality of culture [3]. - V nekotorom smysle imenno vopreki istoricheskoj opredelennosti i ustojchivoj prirode jetogo termina ja i pytajus' pisat' o zapadnoj nacii kak o nejasnoj i vezdesushhej forme zhizni lokal'noj kul'tury [12].

In this example, we observe the division of the sentence and the omission of a minor part of the sentence, as well as a translator's commentary for an adequate understanding of the text. Besides, we have translated the term with the help of constant equivalences:

This locality is more around temporality than about historicity: a form of living that is more complex than 'community'; more symbolic than 'society'; more connotative than 'country'; less patriotic than patrie; more rhetorical than the reason of State; more mythological than ideology; less homogeneous than hegemony; less centred than the citizen; more collective than 'the subject'; more psychic than civility; more hybrid in the articulation of cultural differences and identifications than can be represented in any hierarchical or binary structuring of social antagonism [3]. - Jeta lokal'nost' soprjazhena skoree s temporal'nost'ju, chem s istoricheskim: nekaja forma zhizni, bolee slozhnaja, chem "soobshhestvo"; bolee simvolicheskaja, chem "obshhestvo"; bolee mnogoznachnaja, chem "strana"; menee patriotichnaja, chem patrie; bolee ritoricheskaja, chem gosudarstvennyj interes; bolee mifologicheskaja, chem ideologija; menee odnorodnaja, chem gegemonija. Dannaja lokal'nost' menee centrirovannaja, chem grazhdanin; bolee kollektivnaja, chem "subjekt"; bolee psihicheskaja, chem civilizovannost'; bolee gibridnaja v artikulirovanii kul'turnyh razlichij i identifikacij pola, rasy ili klassa, - chem jeto mozhet byt' reprezentirovano $\mathrm{v}$ kakoj by to ni bylo ierarhicheskoj ili binarnoj strukture social'nogo antagonizma [12].

During the work on the text of the source language, every translator uses the constant equivalences that are already embodied in the dictionaries and literature like in the following example:

Such ideological ambivalence nicely supports Gellner's paradoxical point that the historical necessity of the idea of the nation conflicts with the contingent and arbitrary signs and symbols that signify the affective life of the national culture [3]. - Takaja ideologicheskaja ambivalentnost' prekrasno podtverzhdaet paradoksal'nuju mysl' Gellnera, chto istoricheskaja neobhodimost' idei nacii protivorechit sluchajnym i proizvol'nym znakam i simvolam, kotorye oznachajut jemocional'nuju zhizn' nacional'noj kul'tury [12].

2) Then, we can observe the innovative terms of H.K. Bhabha and their translation into the Russian language. During the translational process, such linguistic units can be translated with the following methods:

A) borrowing matches;

B) calque matches.

For example, the authors have observed the use of borrowing matches, that were transliterated in translation:

In the restless drive for cultural translation, hybrid sites of meaning open up a cleavage in the language of culture [3]. $\mathrm{V}$ neustannom stremlenii $\mathrm{k}$ kul'turnoj peredache gibridnye mestopolozhenija znachenija vskryvajut bresh' $\mathrm{v}$ jazyke kul'tury [12].

The following terms are translated with the relevant structures of the target language, i.e. with the usage of the calque method:

Renan's pedagogical return to the will to nationhood is both constituted and confronted by the circulation of numbers in the plebiscite. This breakdown in the identity of the will is another instance of the supplementary narrative of nationness that 'adds to' without 'adding up' [3]. - Pedagogicheskoe obrashhenie Renana $\mathbf{k}$ vole $\mathbf{k}$ nacional'nosti odnovremenno sozdaetsja i oprokidyvaetsja cirkuljaciej mnozhestvennosti v plebiscite, kotoraja razrushaet identichnost' voli, - primer dopolnenija, kotoroe "dobavljaet", no ne "dopolnjaet" [12].

The main purpose of a translator is to preserve the dominant details of the communicative intentions of the author of the source text, i.e. the cognitive effects on a potential recipient that is associated with the translation of certain information on the investigated object.

\section{CONCLUSION}

The conducted research allows us to conclude that during the translation of the monograph H.K. Bhabha "The Location of Culture", one should take into account the fact that to a greater or lesser extent, one should maintain an academic presentation, which means the accuracy of the material, the objectivity and the exclusion of individual involvement in the writing style. The desire to captivate the reader is not the main aim of the author, which does not make the writing style simplified and adapted. Thus, during the translation, for a translator, it is necessary to maintain a strict scientific exposition.

One the condition of an adequate translation of this type of a text is a complete transferring of its meta-language, primarily terminological. It should be noted that the fundamental error in the terms translation of post-colonial studies, taken from a monograph in the field, is that the translators may seek to find a literal match of a foreign term in the Russian language. This approach is not entirely correct, due to the fact that, firstly, the specifics of the realities of the foreign scientific fact can be erased. And secondly, in the target text, an error can be introduced due to the fact that these terms can express the 
concepts that are unique in source language reality, and therefore does not comply to the realities, accepted in the special materials of the target language. Thus, the correct understanding and translation of terms depend not only on good knowledge of the language but also on the knowledge of the realities of source and target research tradition in translation studies.

The prospects of studying the translation features of scientific texts describing the post-colonial discourse include:

- The study of the linguistic means creating a worldview of the author of the scientific text written in the context of postcolonial research paradigm.

- The analysis of the influence of an individual translator on the translation process of scientific texts.

Overall, this provided study has allowed us to consider the characteristics of the adequate communicative and structurally equivalent translation of scientific texts in the field of postcolonial studies as a specific type of text.

\section{References}

[1] M. Wolf, Constructing a Sociology of Translation. Amsterdam / Philadelphia: John Benjamins, 2007.

[2] A. Milostivaya, "On perception of culture codes in German translations (based on works by M. Bulgakov)," Procedia, Social and Behavioral Sciences, vol. 231, pp. 229-236, 2016.

[3] H.K. Bhabha, The Location of Culture. London: Routledge, 1994.

[4] W. Benjamin, "The Task of Translator" in Illuminations (H. Zohn Trans.), pp. 74-89, 1973.

[5] J. Derrida, "Freud's Legacy" in The Postcard: From Socrates to Freud and Beyond. Chicago: The University of Chicago Press, pp. 292-337, 1987.

[6] J. Derrida, "Les Tours de Babel" in Difference in Translation. (Graham F. Joseph Trans.). London: Cornwell University Press, pp. 165-208, 1985.

[7] R.J.C. Young, "Cultural Translation as Hybridization" in TransHumanities 1, pp. 155-175, 2012.

[8] H. Trivedi, "Translating Culture vs. Cultural Translation" in Reflections, Refractions, Transformations, pp. 277-287, 2007.

[9] T. Shamma, "Postcolonial Studies and Translation" in Monografías de Traducción e Interpretación 1, pp. 183-196, 2009.

[10] L.S. Barhudarov, Language and Translation (Jazyk i perevod). Moscow: International Relations Publishing, 1975.

[11] V.N. Komissarov, Introducing Modern Translation Studies (Vvedenie v sovremennoe perevodovedenie). Moscow: ETS Publishing, 2002.

[12] H.K. Bhabha, "The Location of Culture" (Mestonahozhdenie kul'tury) in CrossRoads 3-4 (G. Gobzem Trans.), pp. 161-192, 2005. 